\title{
Effect of breed and gender on bovine liver cytochrome P450 3A (CYP3A) expression and inter-species comparison with other domestic ruminants
}

\author{
Mauro DACASTO ${ }^{\mathrm{a} *, * *}$, Claudine EECKHOUTTE ${ }^{\mathrm{b}}$, \\ Francesca CAPOLONGO ${ }^{\mathrm{a}}$, Jacques DUPUY ${ }^{\mathrm{b}}$, Monica CARLETTI ${ }^{\mathrm{c}}$, \\ Cécile CALlÉJA ${ }^{\mathrm{b}}$, Carlo NeBBia ${ }^{\mathrm{c}}$, Michel AlviNeRIE $^{\mathrm{b}}$, Pierre GAlTIER $^{\mathrm{b}}$ \\ a Dipartimento di Sanità Pubblica, Patologia Comparata ed Igiene Veterinaria, Area di Farmacologia e \\ Tossicologia, Università di Padova, 35020 Agripolis Legnaro (Padova), Italia \\ b Institut National de la Recherche Agronomique, UR66, Laboratoire de Pharmacologie-Toxicologie, \\ 31931 Toulouse, France \\ c Dipartimento di Patologia Animale, sezione di Farmacologia e Tossicologia, Università di Torino, \\ 10095 Grugliasco (Torino), Italia
}

(Received 17 June 2004; accepted 8 October 2004)

\begin{abstract}
The cytochrome P450 (P450) superfamily represents a group of relevant enzymes in the field of drug metabolism and several exogenous or constitutional factors contribute to regulate its expression. Cattle represent an important source of animal-derived food-products and studies concerning the P450 expression are needed for the extrapolation of pharmacotoxicological data from one species to another and for the evaluation of the consumer's risk associated with the consumption of harmful residues found in foodstuffs. In the present study, possible breed-, genderand species-differences in P4503A (the P450 subfamily more expressed in the human liver) expression were studied in vitro in Piedmontese (PDM) and Limousin (LIM) meat cattle breeds of both sexes and in domestic Ruminants (cattle, sheep and goats). Cytochrome P450 and P4503A contents as well as CYP3A-dependent drug metabolising enzymes (DME) were measured in liver microsomes. Significant lower levels of P450 $(P<0.001)$ and P4503A $(P<0.05)$ contents were observed in PDM vs. LIM of both sexes; the P4503A-dependent DME activities were significantly ( $P$ values ranging from 0.05 up to 0.001$)$ higher in PDM cattle, particularly in males. A gendereffect in DME activities was noticed $(P<0.05)$ only in PDM male cattle. With regards to the species, the expression of both P4503A apoprotein and some of the related DME activities were more pronounced in sheep $(P<0.01$ vs. cattle $)$ and in goats $(P<0.05$ vs. sheep; $P<0.01$ vs. cattle $)$ than in cattle. The significant differences in P4503A expression observed in LIM and PDM cattle are consistent with previously published data on strain- and breed-differences pointed out in rats and men. As far as a possible sex-effect is concerned, no clear-cut evidence is likely to be drawn. Finally, P4503A expression was more relevant in small ruminants.
\end{abstract}

ruminants / liver drug metabolism / CYP3A / gender / breed

\footnotetext{
* Corresponding author: mauro.dacasto@unipd.it

** Recipient of an OECD Fellowship of the Cooperative Research Programme "Biological Resource Management for Sustainable Agricultural Systems"
} 


\section{INTRODUCTION}

The cytochrome P450 (P450, CYP) superfamily constitutes a multigene membrane-bound enzyme system which catalyses oxidation of both xenobiotics (e.g. drugs, environmental pollutants, dietary constituents) and relevant endogenous compounds (like steroids and bile acids). These haemcontaining microsomal proteins have been classified into families and subfamilies, based on their amino acid sequences and genes coding for the enzymes: those sharing more than $40 \%$ sequence identity are assigned to the same family, whereas those with more than $55 \%$ identity are assigned to the same subfamily (e.g. CYP1 and CYP1A, respectively) $[39,43]$. Currently, at least 17 mammalian CYP gene families have been recognised, and those belonging to families 1-4 are primarily involved in drug metabolism [16].

The P4503A subfamily (CYP3A), discovered in the early $1980 \mathrm{~s}$, is a distinct form of $\mathrm{P} 450$ responsible for the oxidative metabolism of most drugs clinically used as well as of endogenous steroid hormones; it is composed of several distinct enzymes (e.g. CYP3A2, CYP3A6), which have been characterised by immunochemistry, catalytic activities and $c$ DNA cloning and expression $[31,43]$. Several lines of evidence indicate that mammalian CYP3A genes are regulated by the pregnane $X$ receptor (PXR; NR1I2), a member of the nuclear receptor family of ligand-activated transcription factors [23]; as a result of this, they are likely to be induced by glucocorticoids (e.g. dexamethasone), pregnane compounds (e.g. pregnenolone $16 \alpha$-carbonitrile) and macrolide antibiotics (e.g. rifampicin). Another characteristic feature is their age- and sexdependent regulation of expression; gender and age represent some constitutional factors (together with species, strain and pathophysiological conditions) that are likely to contribute to the modulation of the overall biotransformation capacity [31, 35, 43, 45].

In humans, CYP3A4 has been immunologically detected in the liver, the gastroin- testinal tract and the kidneys. In the liver, it represents the most abundant CYP isoform, accounting for about $30 \%$ of total P450 spectrophotometrically detectable; in the gastrointestinal tract, CYP3A4 decreases from the duodenum to the colon $(50 \%$ and $1.5 \%$ of the hepatic level, respectively) [19, $31,39]$.

Historically, studies concerning both $\mathrm{P} 450$ expression and regulation have always received very little attention in veterinary food-producing species (e.g. cattle, swine, poultry), compared to man and laboratory animals. These species are often exposed to drugs, pesticides or pollutants potentially harmful not only for the animal itself, but also for humans as a consequence of the accumulation of residues in animal edible tissues [34, 37, 49]. Studies concerning the P450 expression in veterinary species might therefore be helpful (1) for the extrapolation of pharmacotoxicological data from one species to another; (2) the evaluation of the consumer's risk associated with the consumption of foodstuffs derived from animals illegally treated with drugs (e.g. B-agonists, anabolics) or exposed to contaminants; and (3) for the extension of the licenses of use for certain veterinary drugs from major to minor or exotic species $[37,50]$.

In the present study, the effects of some constitutional factors (species, breed and gender) upon the liver CYP3A expression were investigated in domestic ruminants, particularly the breed- and gender-effects were studied in two typical French and Italian meat cattle breeds (Limousin and Piedmontese, respectively), whereas the possible species-difference were evaluated in the adult female sheep, goats and cattle.

\section{MATERIALS AND METHODS}

\subsection{Chemicals}

$\left[{ }^{14} \mathrm{C}\right]$-testosterone (radiochemical purity greater than $97 \%$, specific activity $55.5 \mathrm{mCi} /$ mmol) was obtained from $\mathrm{NEN}^{\mathrm{TM}}$ Life 
Science Products, Inc. (Boston, MA, USA). Methylene chloride, acetonitrile, and methanol were from Carlo Erba (Milano, Italia). Thin layer chromatography (TLC) plates (silica gel $60, \mathrm{~F}_{254}$, aluminium sheets) were from Merck (VWR International, Pessac, France). All other reagents and chemicals (including testosterone metabolites) were from Sigma Chimie (Saint-Quentin, France). Distilled deionised water was used in all studies.

\subsection{Animals}

The effects of breed and gender upon the bovine liver CYP3A expression were studied on 25 Limousin (LIM: 18 males and 7 females) and 24 Piedmontese (PDM: 12 males and 12 females) cattle. The animals were about 15-18 months old and came from private breeding farms located in France (LIM) or in Italy (PDM).

In order to study the species-differences in ruminant liver CYP3A expression, 4 crossbred goats (GT), 4 Lacaune sheep $(\mathrm{OV})$ and 5 Blonde d'Aquitaine cattle (CA) were used. The animals (all adult females) came from private French farms.

\subsection{Preparation of liver microsomal subcellular fractions}

At slaughterhouses, located either in Italy (PDM) or in France (LIM, GT, OV, CA), liver samples free from macroscopic lesions were collected from animals immediately after exsanguination, washed in chilled isotonic potassium chloride and frozen in liquid nitrogen. Once in the laboratory, they were stored at $-80{ }^{\circ} \mathrm{C}$ until use. Microsomal subcellular fractions were isolated by differential ultracentrifugation as reported elsewhere [10]. The protein concentration was determined with bicinchoninic acid, using bovine serum albumin as the standard [54].

\subsection{Total P450 content, CYP3A immunoblotting and CYP3A-dependent drug metabolising enzyme (DME) activities}

All laboratory determinations were carried out at the INRA UR66 (Laboratoire de Pharmacologie et Toxicologie, Toulouse, France), using standardised conditions.

The total P450 content was determined as the carbon monoxide difference spectrum of sodium dithionite-reduced microsomal suspensions [38].

The CYP3A immunoblotting was executed according to the methods of Laemmli [25] and Towbin et al. [57]. Aliquots of microsomal proteins $(2 \mu \mathrm{g})$, harvested in a protein sample loading buffer, were submitted to sodium dodecyl sulphate (SDS)polyacrylamide gel electrophoresis and Western blotting. Nitrocellulose membranes were first incubated with a polyclonal rabbit antisheep CYP3A IgG (dilution 1/500), previously purified and developed in this same laboratory [41], then with rabbit anti-sheep immunoglobulins (dilution 1/1000) and, finally, with peroxidase-labelled sheep antirabbit immunoglobulins (dilution 1/500). Proteins were detected using the SuperSignal ${ }^{\circledR}$ Substrate Western Blotting kit (Interchim, Montlucon, France) and quantified by the Gel Doc $1000^{\circledR}$ documentation system (Bio-Rad, Milano, Italia).

The CYP3A-dependent DME activities were measured using erythromycin, ethylmorphine and testosterone as model substrates. The $N$-dealkylation of erythromycin and ethylmorphine (1 mM final concentration) were measured using $40 \mathrm{mmol} / \mathrm{L}$ $\mathrm{NADPH}, 5 \mathrm{mmol} / \mathrm{L} \mathrm{MgCl}_{2}$ and $1 \mathrm{mg}$ microsomal protein in a final volume of $1 \mathrm{~mL}$ of $0.1 \mathrm{~m} / \mathrm{L}$ phosphate buffer ( $\mathrm{pH} 7.4)$. After 20 min of incubation at $37^{\circ} \mathrm{C}$ in a shaking water bath, the reaction was stopped by adding $250 \mu \mathrm{L}$ chilled $25 \%$ (w/v) trichloroacetic acid; the tubes were then centrifuged $\left(4{ }^{\circ} \mathrm{C}\right)$ and the amount of released formaldehyde in the supernatant was determined 
with the Nash reagent [59]. The 6ß- and $2 \beta$-hydroxylation of $\left[{ }^{14} \mathrm{C}\right]$-testosterone were measured by TLC, modifying the method reported by Larroque et al. [27] for progesterone. Briefly, microsomes $(0.25 \mathrm{mg})$ and $\left[{ }^{14} \mathrm{C}\right]$-testosterone (40 nCi, $207.8 \mu \mathrm{g} /$ assay) were diluted in $1 \mathrm{~mL}$ (final volume) of $50 \mathrm{mM}$ potassium phosphate buffer, $\mathrm{pH}$ 7.4. After 10 min preincubation at $37^{\circ} \mathrm{C}$, the reaction was started by the addition of NADPH ( $1 \mathrm{mM}$, final concentration). Samples were incubated for $10 \mathrm{~min}$ at $37^{\circ} \mathrm{C}$ with shaking and then the reaction was stopped by the addition of $2 \mathrm{~mL}$ ice cold $\left(4{ }^{\circ} \mathrm{C}\right)$ methylene chloride, followed by vigorous shaking. After centrifugation, oxidation products were further extracted with $2 \mathrm{~mL}$ methylene chloride and $2 \mathrm{~mL}$ acetonitrile. Combined extracts were dried with sodium sulphate, evaporated at $60{ }^{\circ} \mathrm{C}$ under nitrogen, dissolved in $40 \mu \mathrm{L}$ methanol and applied onto $0.25 \mathrm{~mm}$ thick silica gel TLC plates. These were developed twice with a mobile phase consisting of chloroform/ethyl acetate/ethanol (4:1:0.7). After solvent evaporation, TLC plates were kept at room temperature, for $72 \mathrm{~h}$, in a cassette with $\mathrm{X}-\mathrm{AR}$ (Kodak ${ }^{\circledR}$ ) films and then developed. The identity of metabolites (androstenedione, $2 \alpha-, 2 \beta-, 6 \beta-, 7 \alpha-$ and $16 \alpha$-hydroxytestosterone) was identified by co-chromatography and UV detection with authentic unlabelled standards. The microsomal activity for each metabolite was expressed as arbitrary units (AU) recovered by the analysis with the same Chemi-Doc ${ }^{\circledR}$ system cited above.

All the activities were expressed as turnover number (TON), according to Kawalek and El Said [21].

\subsection{Statistics}

Data were expressed as mean values \pm SEM Statistical analysis (Graph Pad Instat 2.01, San Diego, CA, USA) was performed either by the Student $t$-test (breed- and gender-effects on CYP3A expression) or the one-way ANOVA followed, if appropriate,
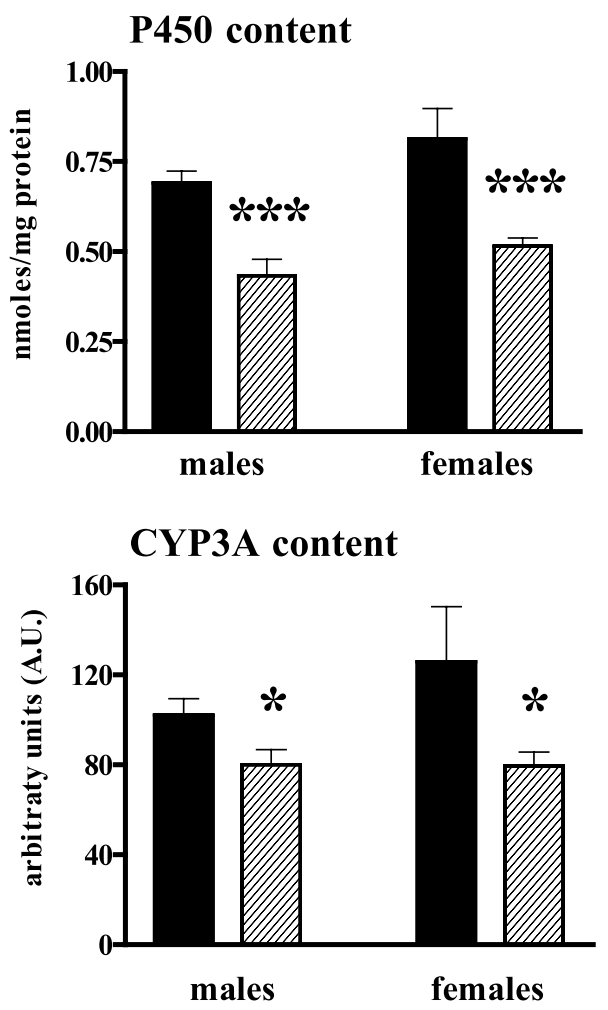

Figure 1. Effect of breed upon the liver $\mathrm{P} 450$ and CYP3A contents. Values are expressed as means

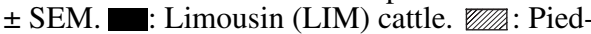
montese (PDM) cattle. $* P<0.05$; *** $P<0.001$ (Student $t$-test).

by the Tukey post-tests (species-differences in CYP3A expression).

\section{RESULTS}

\subsection{Effect of breed on bovine liver CYP3A expression}

\subsubsection{Total P450 content and CYP3A immunoblotting}

In PDM cattle, independently from the sex, both total P450 and CYP3A apoprotein contents were significantly lower $(P<0.001$ and $P<0.05$, respectively) than the respective values measured in LIM cattle (Fig. 1). 
ETDEM

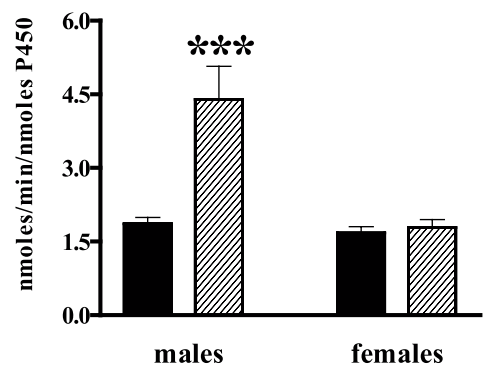

ERDEM

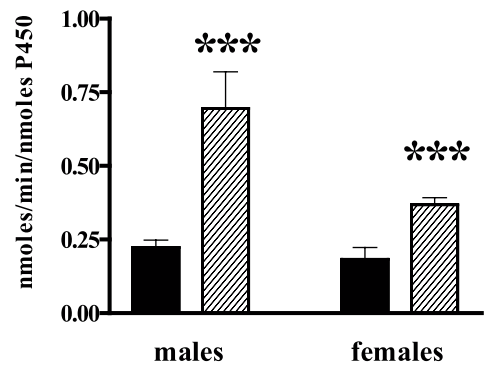

6ß-OHT

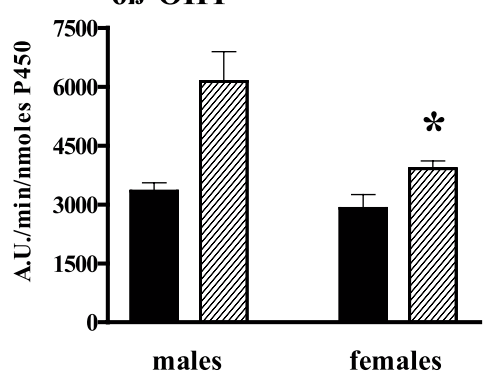

2ß-OHT

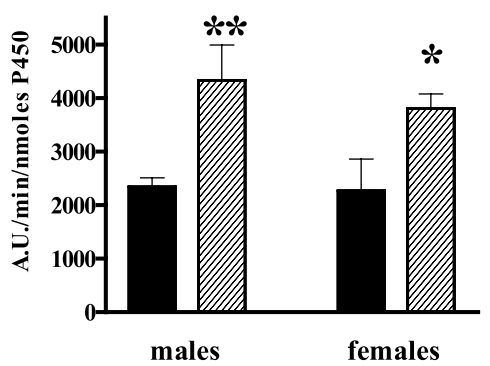

Figure 2. Effect of breed upon the liver CYP3A-dependent DME activities. Values are expressed as means \pm SEM. : Limousin (LIM) cattle. Vuma: Piedmontese (PDM) cattle. ETDEM: ethylmorphine $N$-demethylase. 6B-OHT: testosterone 6B-hydroxylase. ERDEM: erythromycin $N$-demethylase. 2ß-OHT: testosterone 2ß-hydroxylase. ${ }^{*} P<0.05$; ** $P<0.01$; *** $P<0.001$ (Student $t$-test).

\subsubsection{CYP3A-dependent DME activities}

In Figure 2, CYP3A-related enzyme activities, measured in male and female PDM and LIM cattle, using known chemical probes, are reported. Apart from ethyl-morphine $N$-demethylase (ETDEM) in females, significantly higher CYP3A-dependent catalytic activities were noticed, both in males and females, in PDM cattle. The level of statistical significance $(P<0.05, P<0.01$, $P<0.001)$ varied as a function of the marker substrate used. In Figure 3, an example of autoradiograms obtained following the incubation of liver microsomal subcellular fractions with $\left[{ }^{14} \mathrm{C}\right]$-testosterone is presented.

\subsection{Effect of gender on bovine liver CYP3A expression}

\subsubsection{Total P450 content and CYP3A immunoblotting}

In Table I, the effect of gender upon both P450 and CYP3A contents as well as on CYP3A-dependent DME activities in the liver of LIM and PDM cattle is reported. No sex differences in the amount of total P450 as well as of the CYP3A apoprotein were ever observed in both meat cattle breeds.

\subsubsection{CYP3A-dependent DME activities}

In LIM cattle, confirming what was previously observed at the P450 or CYP3A 


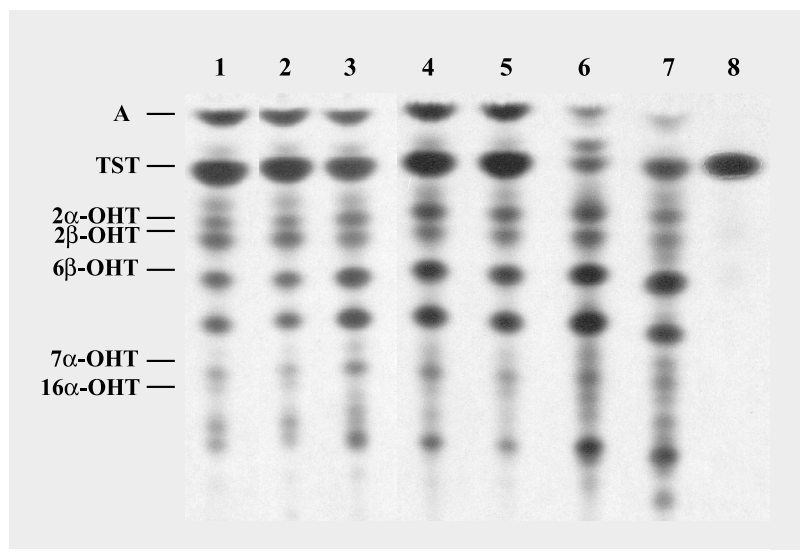

Figure 3. Autoradiogram of oxidative products formed from $\left[{ }^{14} \mathrm{C}\right]$-testosterone by liver microsomal fractions from different breeds of cattle. (lane 1 to 5: male PDM, female PDM, female Blonde d'Aquitaine cattle, female LIM, male LIM, respectively), goat (lane 6) and sheep (lane 7). Experimental conditions are reported in the Materials and Methods section. Lane 8: testosterone without microsomes. A: androstenedione. TST: testosterone. $2 \alpha$-OHT: $2 \alpha$-hydroxytestosterone. $2 \beta$-OHT: $2 \beta$-hydroxytestosterone. $6 \beta$-OHT: $6 \beta$-hydroxytestosterone. $7 \alpha$-OHT: $7 \alpha$-hydroxytestosterone. $16 \alpha$-OHT: $16 \alpha$-hydroxytestosterone.

Table I. Effect of gender upon the liver P450 content ${ }^{\dagger}$, immunoblotting ${ }^{\ddagger}$ and CYP3A-DME ${ }^{\S}$ activities in Limousin (LIM) and Piedmontese (PDM) cattle.

\begin{tabular}{lcccccc}
\hline \multicolumn{2}{c}{ P450 } & CYP3A & ETDEM & 6ß-OHT & ERDEM & 2ß-OHT \\
\hline LIM & & & & & & \\
Males & $0.69 \pm 0.03$ & $102.00 \pm 7.44$ & $1.86 \pm 0.13$ & $3343.2 \pm 209.8$ & $0.22 \pm 0.02$ & $2341.5 \pm 169.4$ \\
Females & $0.81 \pm 0.08$ & $125.81 \pm 24.59$ & $1.68 \pm 0.12$ & $2906.2 \pm 344.7$ & $0.18 \pm 0.04$ & $2268.5 \pm 589.7$ \\
PDM & & & & & & \\
Males & $0.43 \pm 0.04$ & $80.27 \pm 6.62$ & $4.40 \pm 0.67$ & $6134.5 \pm 758.9$ & $0.70 \pm 0.12$ & $4329.8 \pm 657.6$ \\
Females & $0.52 \pm 0.02$ & $79.49 \pm 6.17$ & $1.79 \pm 0.16 * 3909.0 \pm 200.4 *$ & $0.37 \pm 0.02 *$ & $3800.6 \pm 274.5$ \\
\hline
\end{tabular}

Values are expressed as means \pm SEM

$\dagger$ nmoles/mg protein.

\$: arbitrary units (A.U.).

$\S:$ nmoles/min/nmoles P450 (ETDEM and ERDEM); A.U./min/nmoles P450 (6ß- and 2ß-OHT).

* $P<0.05$ vs. the male of the same breed (Student $t$-test).

apoprotein level, a lack of a gender-effect in CYP3A-dependent DME activities was noticed. By contrast in PDM females, the activities of erythromycin $N$-demethylase (ERDEM), ethylmorphine $N$-demethylation (ETDEM) and testosterone 6ß-hydroxylation $(6 \beta-O H T)$ were significantly $(P<0.05)$ lower than those in the respective males (see Tab. I.).

\subsection{Effect of species on liver CYP3A expression}

\subsubsection{Total P450 content and CYP3A immunoblotting}

The P450 and CYP3A contents in the liver of different ruminant species are reported in Figure 4. The only statistically 

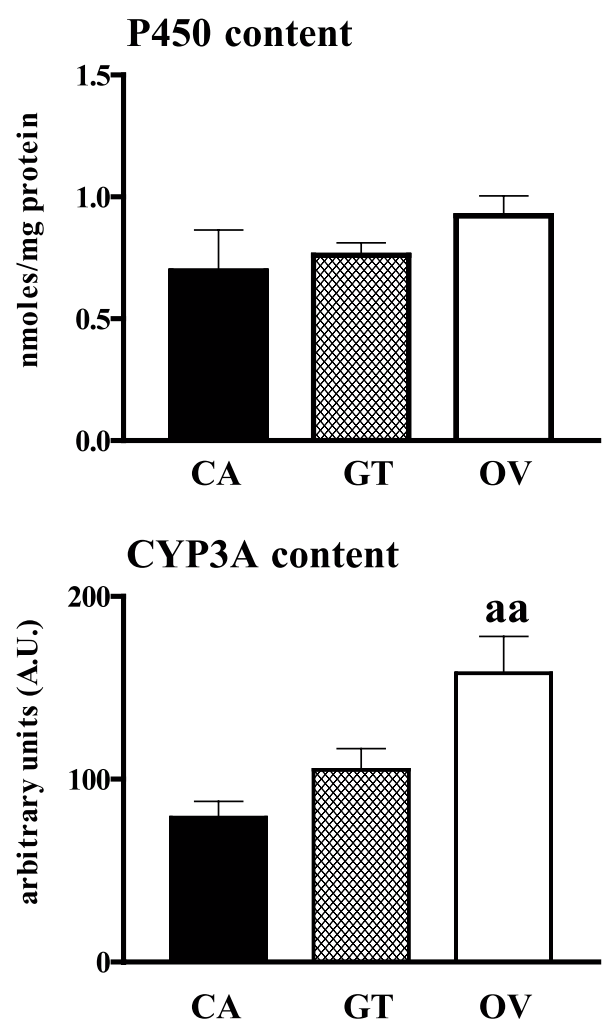

Figure 4. Total P450 and CYP3A contents in the liver of different female ruminant species. Values are expressed as means \pm SEM. Blonde d'Aquitaine cattle (CA). cross-bred goats (GT). $\square$ : Lacaune sheep (OV). ${ }^{\text {aa }} P<0.01$ vs. BA (Tukey post-tests).

significant difference recorded was in immunoblotting results, where $\mathrm{OV}$ showed a higher amount of CYP3A apoprotein compared to CA $(P<0.01)$.

\subsubsection{CYP3A-dependent DME activities}

No difference in the rate of liver hydroxylation of testosterone at positions $6 \beta$ - and $2 \beta$ - was noticed between small ruminants and cattle; by contrast, the former disclosed a higher capability for erythromycin $N$-demethylation $(P<0.01)$. When consid- ering ETDEM, statistically significant differences were reported between GT and OV or CA $(P<0.05$ and $P<0.01$, respectively; see Tab. II).

\section{DISCUSSION}

In the last 25 years, several detailed experiments have been performed by scientists in order to characterise the most important group of xenobiotic drug metabolising enzymes, the P450 [33]. Many studies have mapped out the molecular biology of this superfamily and nowadays it can be divided into many subfamilies, each of which (particularly those belonging to numbers 1 to 4 ) is linked to a different set of drugs [33, 56]; moreover, numerous investigators have identified the substrate specificities of each single isoform [33]. Recently, some studies which report the metabolism of substrates as models for specific enzymatic pathways in liver preparations of farm animals have been published too $[29,37,49,55]$.

It is known that several non pharmacogenetic factors such as age, gender, species, disease factors or exposure to environmental pollutants might contribute to the expression and regulation of hepatic $\mathrm{P} 450$ in man, laboratory species and domestic animals $[14,35]$.

The CYP3A isoform is one of the most important $\mathrm{P} 450$ enzymes involved in the human drug metabolism (CYP3A contributes to the metabolism of about $45 \%-60 \%$ of all currently used drugs); this importance is essentially attributable to its presence in critical tissues (e.g. liver, intestine), wide substrate spectrum, susceptibility to drug interactions as well as interindividual variable expression levels [3, 12, 31, 56].

In the present work, the effect of some physiological factors (namely, breed, gender and species) upon the liver CYP3A expression were studied in CA, GT and OV.

In our experimental conditions, breed was shown to influence the hepatic P450 content $(P<0.001)$ and the level of CYP3A 


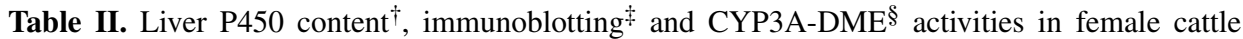
(Blonde d'Aquitaine, CA), cross-bred goats (GT) and Lacaune sheep (OV).

\begin{tabular}{lcccccc}
\hline & P450 & CYP3A & \multicolumn{1}{c}{ ETDEM } & 6B-OHT & \multicolumn{1}{c}{ ERDEM } & 2B-OHT \\
\hline CA & $0.69 \pm 1.70$ & $79.91 \pm 8.90$ & $1.61 \pm 0.22$ & $3646.8 \pm 857.6$ & $0.31 \pm 0.05$ & $2673.8 \pm 704.1$ \\
GT & $0.76 \pm 0.05$ & $105.17 \pm 11.6$ & $5.64 \pm 0.99^{\mathrm{aa}, \mathrm{c}}$ & $2756.7 \pm 351.3$ & $1.27 \pm 0.18^{\mathrm{aa}}$ & $2214.8 \pm 137.4$ \\
OV & $0.92 \pm 0.08$ & $157.84 \pm 20.18$ & $2.38 \pm 0.22$ & $2530.9 \pm 130.9$ & $1.16 \pm 0.19^{\text {aa }}$ & $1490.7 \pm 179.6$ \\
\hline
\end{tabular}

Values are expressed as means \pm SEM.

$\dagger:$ nmoles/mg protein.

\$: arbitrary units (A.U.).

$\S:$ nmoles $/ \mathrm{min} / \mathrm{nmoles}$ P450 (ETDEM and ERDEM); A.U./min/nmoles P450 (6ß- and 2ß-OHT).

c $P<0.05$ vs. $\mathrm{OV}$; aa $P<0.01$ vs. CA (Tukey post-test).

apoprotein $(P<0.05)$, too. Statistically significant differences between LIM and PDM cattle were also confirmed by measuring the in vitro metabolism of selected CYP3Adependent substrates, except for ETDEM. The DME activities were expressed as TON, a kinetic constant that represents a direct correlation between the quantity of product formed per minute per mg of microsomal protein divided by the amount of P450, the specific enzyme system available for catalysing those particular reactions [21]. Despite the overall agreement of data, these results must be considered carefully, since they were obtained using probes suitable for the rat and the human CYP3A and that their relative specificity to bovine CYP3A still remains to be confirmed [49]. Strain and breed-related differences in CYP3A-mediated metabolism have already been demonstrated in man and rats as well $[2,5,26,32]$. As far as cattle are concerned, breed-differences in the disposition of antipyrine (a probe used in clinical pharmacology to determine the effects of individual or environmental factors on DME) have been reported in Blue White Belgian and Friesian calves [8]. Moreover, very recently some differences, at least in the catalytic activity level, were reported in both the oxidative and conjugative liver drug metabolism in PDM, Charolais and Blonde d'Aquitaine male cattle (Carletti et al., unpublished results).
Since 1932, gender-related differences in the way by which animals metabolise drugs have been reported [15]; in this respect, a clear sexual dimorphism in the expression of hepatic genes, including some members of the CYP3A subfamily, has been documented in rodents and, particularly, in rats $[1,13,20,24,28,33,42,45]$. In cattle and other domestic animals, possible gendereffects on pharmacokinetics, including P450 drug metabolism, have already been described $[4,6,8,9,17,18,36,40,52]$.

In the present study, male PDM cattle showed significantly higher CYP3A-dependent DME activities compared to the female ones, with the mere exception of $2 \beta-\mathrm{OHT}$ (whose enzymatic activity was yet lower in females); by contrast, no gender-difference was ever noticed in LIM cattle. These latter results seem to confirm those previously obtained, in the cattle of the same breed, by Dupuy et al. [9]. In this study, a lack of a gender-effect was demonstrated in the in vitro liver drug metabolism of ivermectin, an antiparasitic macrocyclic lactone widely used in both veterinary and human medicine. This drug is known to be metabolised by CYP3A in man [61] whereas it might act either as a mild inducer of CYP3A in wild ruminants [53] or as a substrate of $p$-glycoprotein in the lamb [11]. Definitely more difficult to explain are the highest catalytic activities found in male PDM. In our experimental conditions, the gender-effect was only observed at the catalytic activity 
level since immunoblotting showed no variation in the amount of CYP3A apoprotein; furthermore, RNA isolation and northern blot analysis of liver samples hybridised with bovine CYP3A specific oligonucleotide probes gave misleading results. In the rat, the sexual dimorphism in xenobiotic metabolism is regulated by growth hormone $(\mathrm{GH})$, and such an effect was demonstrated at both catalytic activity and gene expression levels [13,33, 45]. Besides, recombinant bovine somatothropin has been proven to modulate the activity of liver P450 enzymes in the rat [60]. By considering, as in the rat, a possible regulation of CYP3A expression by $\mathrm{GH}$, it has been previously demonstrated that Hereford and Aberdeen-Angus bulls had significantly higher serum GH levels than heifers of the same age [22]; by contrast, it has also been reported that GH plasma concentrations did not differ significantly among Holstein, Simmental, Normandy and Blue White Belgian cows [44]. Based on our results and bibliographic evidence, no clear-cut conclusions can therefore be made.

On a literature basis, it is known that among the most investigated constitutional factors are the species-differences in $\mathrm{P} 450$ dependent DME activities [35]; this is clearly evident for ruminants $[10,30,46$, $51,53,55]$. In the present study, no difference was noticed in P450 concentrations; by contrast, the amount of CYP3A apoprotein was significantly higher in $\mathrm{OV}$ as compared to cattle (CA); the order of magnitude was $\mathrm{CA}<\mathrm{GT}<\mathrm{OV}$ and these results confirm the presence of species-differences in the expression of some $\mathrm{P} 450$ isoforms and their lower expression, including CYP3A, in cattle vs. small ruminants $[55,58]$. There are several studies reporting the in vitro metabolism of many P450 isoform model substrates in liver preparations from ruminants [46]. In our study, the CYP3A-dependent $N$-demethylations of erythromycin and ethylmorphine were significantly higher in small ruminants (GT $>\mathrm{OV}$ ) than in $\mathrm{CA}$, confirming previously published results [7, $47,48,51,58]$. However, no species-differences were observed in the hydroxylation of testosterone at the $6 \beta$ - and $2 \beta$-positions, two reactions catalysed by CYP3A also in ruminants [30]. In a recent paper, a relatively high $63-\mathrm{OHT}$, compared to GT or $\mathrm{CA}$, was noticed in OV [55]. As a possible explanation, in our study the DME activities were always expressed as turnover number and the comparative interpretation of our results with data reported in the literature in terms of possible inter-species differences could be misleading, especially when the concentration of P450 is not reported. Moreover, in certain instances, the rates of metabolism of marker substrates might be of limited value in the comparative evaluation of drug metabolism between species. As an example, among ruminants, P450 concentrations in some studies were not significantly different between cattle and sheep, while in others they were [46].

In conclusion, in the present study, marked breed-differences in CYP3A expression have been reported in both sexes of two meat cattle breeds (PDM and LIM). Besides, a gender-effect was noticed in PDM cattle whereas cattle were demonstrated as the ruminant domestic species with the lower constitutive CYP3A expression. From these results, it appears that the pattern of xenobiotic biotransformation should be consistently tested on all the target species. So, the extrapolation of data from one species to another might be misleading and then dangerous, first for the animal administered with drugs or exposed to xenobiotics and, in the second instance for consumers, in terms of the presence of potentially harmful residues in foodstuffs of animal origin.

\section{REFERENCES}

[1] Anakk S., Ku C.Y., Vore M., Strobel H.W., Insights into gender bias: rat cytochrome $\mathrm{P} 450$ 3A9, J. Pharmacol. Exp. Ther. 305 (2003) 703-709.

[2] Balram C., Zhou Q., Cheung Y.B., Lee E.J., CYP3A5*3 and *6 single nucleotide polymorphisms in three distinct Asian populations, Eur. J. Clin. Pharmacol. 59 (2003) 123126. 
[3] Burk O., Wojnowski L., Cytochrome P4503A and their regulation, Arch. Pharmacol. 369 (2004) 105-124.

[4] Capece B.P.S., Castells G., Pérez F., Arboix M., Cristòfol C., Pharmacokinetic behaviour of albendazole sulphoxide enantiomers in male and female sheep, Vet. Res. Commun. 24 (2000) 339-348.

[5] Chelule P.K., Gordon M., Palanee T., Page T., Mosam A., Coovadia H.M., Cassol S., MDR1 and CYP3A4 polymorphisms among African, Indian, and white populations in KwaZuluNatal, South Africa, Clin. Pharmacol. Ther. 74 (2003) 195-196.

[6] Cristòfol C., Navarro M., Franquelo C., Valladares J.-E., Arboix M., Sex differences in the disposition of albendazole metabolites in sheep, Vet. Res. Commun. 78 (1998) 223 231.

[7] Dalvi R.R., Nunn V.A., Juskevich J., Hepatic cytochrome P-450 dependent drug metabolizing enzyme activities in cattle, goats, and sheep, J. Anim. Sci. 10 (1987) 164-168.

[8] Depelchin B.O., Bloden S., Michaux C., Ansay M., Effects of age, sex and breed on antipyrine disposition in calves, Vet. Res. 44 (1988) 135-139.

[9] Dupuy J., Eeckhoutte C., Sutra J.F., Mage C., Alvinerie M., Lack of sex-influence on the in vitro metabolism of ivermectin by hepatic microsomal preparations in cattle, Vet. Res. Commun. 23 (1999) 223-227.

[10] Dupuy J., Escudero E., Eeckhoutte C., Sutra J.F., Galtier P., Alvinerie M., In vitro metabolism of ${ }^{14} \mathrm{C}$-moxidectin by hepatic microsomes from various species, Vet. Res. Commun. 25 (2001) 345-354.

[11] Dupuy J., Larrieu G., Sutra J.F., Lespine A., Alvinerie M., Enhancement of moxidectin bioavailability in lamb by a natural flavonoid: quercetin, Vet. Parasitol. 25 (2003) 337-347.

[12] Evans W.E., Relling M.V., Pharmacogenomics: translating functional genomics into rational therapeutics, Science 286 (1999) 487-491.

[13] Furukawa T., Manabe S., Watanabe T., Sharyo S., Mori Y., Sex difference in the daily rhythm of hepatic P450 monooxygenase activities in rats is regulated by growth hormone release, Toxicol. Appl. Pharmacol. 161 (1999) 219-224.

[14] GuengerichF.P., Cytochrome P450, in: Ioannides C. (Ed.), Enzyme systems that metabolise drugs and other xenobiotics, John Wiley \& Sons Inc., New York, 2002, pp. 33-65.
[15] Harris R.Z., Benet L.Z., Schwartz J.B., Gender effects in pharmacokinetics and pharmacodynamics, Drugs 50 (1995) 222-239.

[16] Honkakoski P., Negishi M., Regulation of cytochrome P450 (CYP) genes by nuclear receptors, Biochem. J. 347 (2000) 321-337.

[17] Janus K., Antoszek J., The effect of sex on antipyrine metabolism in cattle at different ages, J. Vet. Pharmacol. Ther. 22 (1999) 163169.

[18] Janus K., Antoszek J., The effect of sex and age on caffeine pharmacokinetics in cattle, Res. Vet. Sci. 69 (2000) 33-37.

[19] Johnson T.N., Tanner M.S., Tucker G.T., A comparison of the ontogeny of enterocytic and hepatic cytochromes P450 3A in the rat, Biochem. Pharmacol. 60 (2000) 1601-1610.

[20] Kato R., Yamazoe Y., Sex-specific cytochrome $\mathrm{P} 450$ as a cause of sex- and speciesrelated differences in drug toxicity, Toxicol. Lett. 65 (1992) 661-667.

[21] Kawalek J.C., El Said K.R., Maturational development of drug-metabolizing enzymes in sheep, Am. J. Vet. Res. 51 (1990) 17361741.

[22] Keller D.G., Smith V.G., Coulter G.H., King G.J., Serum growth hormone concentration in Hereford and Angus calves: effects of breed, sire, sex, age, age of dam, and diet, Can. J. Anim. Sci. 59 (1979) 367-373.

[23] Kliewer S.A., Goodwin B., Willson T.M., The nuclear pregnane $\mathrm{X}$ receptor: a key regulator of xenobiotic metabolism, Endocr. Rev. 23 (2002) 687-702.

[24] Konno Y., Sekimoto M., Nemoto K., Degawa M., Sex difference in induction of hepatic CYP2B and CYP3A subfamily enzymes by nicardipine and nifedipine in rats, Toxicol. Appl. Pharmacol. 196 (2004) 20-28.

[25] Laemmli U.K., Cleavage of structural proteins during the assembly of the head of bacteriophage T4, Nature 227 (1970) 680-685.

[26] Lamba J.K., Lyn Y.S., Schuetz E.G., Thummel K.E., Genetic contribution to variable human CYP3A-mediated metabolism, Adv. Drug Deliv. Rev. 54 (2002) 1271-1294.

[27] Larroque C., Lange R., Maurel P., Langlois R., van Lier J.E., Rat liver microsomal progesterone metabolism: evidence for differential troleandomycin and pregnenolone $16 \alpha$ carbonitrile inductive effects in the cytochrome P-450 III family, J. Steroid Biochem. 33 (1989) 277-286. 
[28] Lee P.-C., Struve M.F., Werlin S.L., Age and gender effect on the inducibility of steroid metabolizing cytochrome P450 in rat liver, Biochem. Mol. Biol. Int. 34 (1994) 861-870.

[29] Machala M., Nezveda K., Irizar A., Bu-Abbas A., Ioannides C., Expression and inducibility of cytochrome $\mathrm{P} 450$ proteins in the liver of chick embryo, Arch. Toxicol. 71 (1996) 57-63.

[30] Machala M., Souček P., Neča J., Ulrich R., Lamka J., Szotáková B., Skálová L., Interspecies comparisons of hepatic cytochrome P450 enzyme levels in male ruminants, Arch. Toxicol. 77 (2003) 555-560.

[31] Maurel P., The CYP3 family, in: Ioannides C. (Ed.), Cytochrome P450: Metabolic and Toxicological Aspects, CRC Press, Boca Raton, Florida, 1996, pp. 241-270.

[32] Morita K., Maeda Y., Masuda M., Kazusaka A., Imaoka S., Funae Y., Fujita S., Strain differences in CYP3A-mediated C-8 hydroxylation (1,3,7-trimethyluric acid formation) of caffeine in Wistar and Dark Agouti rats, Biochem. Pharmacol. 55 (1998) 1405-1411.

[33] Mugford C.A., Kedderis G.L., Sex-dependent metabolism of xenobiotics, Drug Metab. Rev. 30 (1998) 441-498.

[34] Natsuhori M., van Raak M., Ligtenberg M., Kleij L., ten Berge D., Zweers-Zeilmaker W.M., de Groene E.M., van Miert A.S.J.P.A.M., Witkamp R.F., Horbach G.J., Isolation of a bovine full lenght cytochrome P450 (CYP3A) cDNA sequence and its functional expression in V79 cells, Environ. Toxicol. Pharmacol. 3 (1997) 17-24.

[35] Nebbia C., Biotranformation enzymes as determinants of xenobiotic toxicity in domestic animals, Vet. J. 161 (2001) 238-252.

[36] Nebbia C., Dacasto M., Rossetto Giaccherino A., Rattazzi C., Gobbi C.M., Carletti M., Indagini preliminari sullo sviluppo post-natale degli enzimi farmaco-metabolizzanti nel cavallo, Atti S.I.S. Vet. LIII (1999) 309-310.

[37] Nebbia C., Dacasto M., Rossetto Giaccherino A., Giuliano Albo A., Carletti M., Comparative expression of liver cytochrome P450dependent monooxygenases in the horse and in other agricultural and laboratory species, Vet. J. 165 (2003) 53-64.

[38] Omura T., Sato R., The carbon monoxide binding pigment of liver microsomes. II. Solubilisation, purification, properties, J. Biol. Chem. 239 (1964) 2379-2385.

[39] Ortiz de Montellano P.R., The cytochrome P450 oxidative system, in: Woolf T.F. (Ed.), Handbook of drug metabolism, Marcel Dekker, New York, 1999, pp.109-130.
[40] Pampori N.A., Shapiro B.H., Sexual dimorphism in avian hepatic monooxygenases, Biochem. Pharmacol. 46 (1993) 885-890.

[41] Pineau T., Galtier P., Bonfils C., Derancourt J., Maurel P., Purification of a sheep liver cytochrome P-450 from the P450IIIA gene subfamily. Its contribution to the $N$-dealkylation of veterinary drugs, Biochem. Pharmacol. 39 (1990) 901-909.

[42] Pozzetti L., Paolini M., Barillari J., CantelliForti G., Induction and suppression of murine CYP-mediated biotransformation by dithianon: organ- and sex-related differences, Cancer Lett. 141 (1999) 47-56.

[43] Quattrochi L.C., Guzelian P.S., CYP3A regulation: from pharmacology to nuclear receptors, Drug Metab. Dispos. 29 (2001) 615-622.

[44] Renaville R., Massart S., Shojae D., Prandi A., Devolder A., Sneyers M., Falaki M., Burny A., Portetelle D., Growth hormone, insulin growth factor-I and their plasma binding proteins in different cattle breeds, Zootecnia Nutrizione Animale 21 (1995) 75-84.

[45] Robertson G.R., Farrell G.C., Liddle C., Sexually dimorphic expression of rat CYP3A9 and CYP3A18 genes is regulated by growth hormone, Biochem. Biophys. Res. Commun. 242 (1998) 57-60.

[46] Short C.R., Consideration of sheep as a minor species: comparison of drug metabolism and disposition with other domestic ruminants, Vet. Hum. Toxicol. 36 (1994) 24-40.

[47] Short C.R., Barker S.A., Flory W., Comparative drug metabolism and disposition in minor species, Vet. Hum. Toxicol. 30 (1988) 2-8.

[48] Short C.R., Flory W., Hsieh L.C., Aranas T., Ou S.P., Weissinger J., Comparison of hepatic drug metabolizing enzyme activities in several agricultural species, Comp. Biochem. Physiol. C 91 (1988) 419-424.

[49] Sivapathasundaram S., Magnisali P., Coldham N.G., Howells L.C., Sauer M.J., Ioannides C., A study of the expression of the xenobioticmetabolising cytochrome $\mathrm{P} 450$ proteins and of testosterone metabolism in bovine liver, Biochem. Pharmacol. 62 (2001) 635-645.

[50] Sivapathasundaram S., Magnisali P., Coldham N.G., Howells L.C., Sauer M.J., Ioannides C., Cytochrome $\mathrm{P} 450$ expression and testosterone metabolism in the liver of deer, Toxicology 187 (2003) 49-65.

[51] Sivapathasundaram S., Sauer M.J., Ioannides C., Xenobiotic conjugation systems in deer 
compared with cattle and rat, Comp. Biochem. Physiol. C 134 (2003) 169-173.

[52] Skaanild M.T., Friis C., Cytochrome P450 sex differences in minipigs and conventional pigs, Pharmacol. Toxicol. 85 (1999) 174-180.

[53] Skálová L., Szotáková B., Machala M., Neča J., Souček P., Havlasová J., Wsól V., Kř́ídová L., Kvasničková E., Lamka J., Effect of ivermectin on activities of cytochrome P450 isoenzymes in mouflon (Ovis musimon) and fallow deer (Dama dama), Chem.-Biol. Interact. 37 (2001) 155-167.

[54] Smith P.K., Krohn R.I., Hermason G.T., Mallia A.K., Gartner F.H., Provenzo M.D., Fujinoto E.K., Goeke N.M., Olson B.J., Klenk D.C., Measurement of protein using bicinchoninic acid, Anal. Biochem. 150 (1985) 76-85.

[55] Szotáková B., Baliharová V., Lamka J., Nožinová E., Wsól V., Velík J., Machala M., Neča J., Souček P., Š̉usová S., Skálová L., Comparison of in vitro activities of biotransformation enzymes in pig, cattle, goat and sheep, Res. Vet. Sci. 76 (2004) 43-51.

[56] Tanaka E., Gender-related differences in pharmacokinetics and their clinical significance, J. Clin. Pharm. Ther. 24 (1999) 339346.
[57] Towbin H., Staehelin T., Gordon J., Electrophoretic transfert of proteins from polyacrylamide gels to nitrocellulose sheets: procedure and some applications, Proc. Natl. Acad. Sci. USA 76 (1979) 4350-4354.

[58] Van't Klooster G.A.E., Blaauboer B.J., Noordhoek A., van Miert A.S.J.P.A.M., Cytochrome P450 induction and metabolism of alkoxyresorufins, ethylmorphine and testosterone in cultured hepatocytes from goats, sheep and cattle, Biochem. Pharmacol. 46 (1993) 1781-1790.

[59] Werringloer J., Assay of formaldehyde during microsomal oxidations reactions, Methods Enzymol. C 52 (1978) 297-302.

[60] Witkamp R.F., Kolker H.J., Nijmeijer S.M., Noordhoek J., van Miert A.S., Selective changes in oxidative xenobiotic metabolism in vivo and in vitro after parenteral administration of recombinant bovine somatotrophin to rats, Res. Vet. Sci. 55 (1993) 31-37.

[61] Zeng Z., Andrew N.W., Arison B.H., LufferAtlas D., Wang R.W., Identification of cytochrome P4503A4 as the major enzyme responsible for the metabolism of ivermectin by human liver microsomes, Xenobiotica 28 (1998) 313-321. 